\title{
Differentiating cave Aspidoras catfish from a karst area of Central Brazil, upper rio Tocantins basin (Siluriformes: Callichthyidae)
}

\author{
Sandro Secutti ${ }^{1}$, Roberto E. Reis ${ }^{2}$ and Eleonora Trajano ${ }^{1}$
}

Two cave populations of Aspidoras albater catfish with reduced eyes and pigmentation were recently found near the city of Posse, São Domingos karst area, Goiás State, representing the first known case of a troglomorphic callichthyid catfish. Cave specimens are described and compared to epigean specimens of $A$. albater, but morphometric differences between the epigean and the cave populations are not adequate to delimit as distinct species.

Duas populações de Aspidoras albater com olhos e pigmentação reduzidos foram descobertas recentemente em cavernas do município de Posse, área cárstica de São Domingos, Goiás, representando o primeiro caso conhecido de Callichthyidae troglomórfico. Os espécimes cavernícolas são descritos e comparados com espécimes epígeos de A. albater, mas as diferenças morfométricas entre eles não são suficientes para delimitá-los como espécies distintas.

Key words: Aspidoras albater, Cave fish, Goiás State, Neotropical, Population differentiation.

\section{Introduction}

At least 37 species of subterranean fishes showing some degree of troglomorphism (basically reduction of eyes and pigmentation) have been found in continental South America, representing almost one quarter of the total number of species recorded worldwide (164 - Proudlove, 2010). Most are Siluriformes belonging to the families Trichomycteridae, Heptapteridae, Loricariidae, and Astroblepidae. As expected in view of its larger area, Brazil harbors the largest number of species (25 up to now - Trajano \& Bichuette, 2010), with representatives of all the above mentioned families except for Astroblepidae, in addition to two non-siluriforms (a characiform, Stygichthys typhlops, and a gymnotiform, Eigenmannia vicentespelaea) and a recently discovered callichthyid catfish, genus Aspidoras.

These fishes differ interspecifically and, in some cases, also inter-populationally, in their degree of eyes reduction and melanic pigmentation, from fish completely depigmented and without externally visible eyes to those with eyes slightly but statistically reduced when compared to epigean (surface) congeners and a paler coloration. Some populations have great variation in these characters, which may show a mosaic distribution; often, the frequencies of different degrees of eye and pigmentation reduction show a distribution tending to normal within the populations (Trajano \& Bichuette, 2010).

These observations are evidence for a gradual differentiation of eyes, pigmentation, and other troglomorphisms in populations confined to subterranean habitats and thus supposed to be genetically isolated. Differences in degree of troglomorphism may be accounted for differences in time of isolation and in differentiation rates, which are influenced by population sizes (which greatly vary - see Trajano, 2001), among other factors (Trajano, 2007). Among the subterranean fishes recently discovered in Brazil, the Aspidoras catfish represents the first reported case of a callichthyid with variably developed eyes, including a considerable proportion of individuals without externally visible eyes and a faint coloration.

The Brazilian genus Aspidoras Ihering, 1907 encompasses 20 nominal species, distributed in southern tributaries of the rio Amazonas (rios Xingu and Araguaia-Tocantins), in the upper rio Paraná basin, and in northeastern and eastern coastal Brazilian rivers. Three species have been reported for the upper rio Tocantins basin, Aspidoras albater Nijssen \& Isbrücker, 1976, A. poecilus Nijssen \& Isbrücker, 1976, and $A$. eurycephalus Nijssen \& Isbrücker, 1976. Herein we compare A. albater with the cave Aspidoras recently discovered near

\footnotetext{
${ }^{1}$ Universidade de São Paulo, Instituto de Biociências, Departamento de Zoologia, Caixa Postal 11461, 05422-970 São Paulo, Brazil. sanoverkill@yahoo.com.br(SS),etrajano@usp.br(ET)

${ }^{2}$ Pontifícia Universidade Católica do Rio Grande do Sul, Laboratório de Sistemática de Vertebrados, Av. Ipiranga 6681, 90619-900 Porto Alegre, Brazil. reis@pucrs.br
} 
Posse, Central State of Goiás, with focus on external morphology. Data on habitat and behavior are also provided.

\section{Material and Methods}

Aspidoras catfish have been collected in epigean streams, and also in one cave, from São Domingos karst area, State of Goiás, in the Parque Estadual de Terra Ronca PETER (these specimens were assigned to A. poecilus; Bichuette \& Trajano, 2003). More recently, specimens of Aspidoras differing from epigean populations by a conspicuous intrapopulational variation in eye size and paler coloration were found in caves near the town of Posse, in the neighborhood of the PETER. We compared these cave populations with samples of Aspidoras albater collected in the same area.

The specimens of Aspidoras have been found in three small limestone caves near Posse, São Domingos karst area, Goiás State, central Brazil: the Anésio III (1405'27.7'S $\left.46^{\circ} 22^{\prime} 59.6^{\prime} \mathrm{W}\right)$, the Russão II ( $14^{\circ} 05^{\prime} 05.3^{\prime}$ 'S $\left.46^{\circ} 23^{\prime} 07.1^{\prime \prime} \mathrm{W}\right)$,

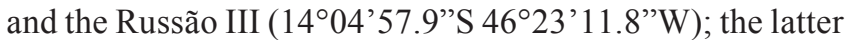
were not collected, thus not included in the morphological study. The small stream inside the cave Anésio III ( $c a .2000$ $\mathrm{m}$ of conduits) is fed during rains by an epigean water course entering directly through the cave entrance (the sinkhole), ca. $5 \mathrm{~m}$ higher relative to the cave base level. We surveyed the first $200 \mathrm{~m}$ inside this cave, where catfish were observed along the permanent small cave stream, from $40 \mathrm{~m}$ inside the cave on. The cave Russão III (about 1,800 m long) is fed by a subterranean stream appearing inside the cave and running towards the cave entrance, without an obvious connection with epigean water courses. Apparently, the cave Russão II (a small conduit ca. $30 \mathrm{~m}$ long) and Russão III are part of the same cave system, water flowing from Russão III to II during rains.

Methodology and terminology for linear measurements and body plate counts follow Reis (1997), with the addition of pectoral spine length, measured from base to bony tip of spine. Morphological measurements were made point-to-point to the nearest $0.1 \mathrm{~mm}$ with digital calipers. Morphometric data are expressed as percents of the standard length (SL), except subunits of the cephalic region which were expressed in percents of head length (HL).

Principal Components Analysis (PCA) was used to investigate morphometric variation among the cave and epigean Aspidoras albater. A total of 20 morphometric variables (Table 1) were taken from 55 specimens representing comparable size ranges: a population from the Anésio III Cave ( $\mathrm{n}=17,21.0-38.8 \mathrm{~mm} \mathrm{SL}$ ), a population from the Russão II Cave $(\mathrm{n}=13,18.9-36.2 \mathrm{~mm} \mathrm{SL})$, and epigean specimens from the córrego Mandassaia, in Monte Alegre and from a creek in the serra da Mesa, Campinaçu ( $\mathrm{n}=25,16.8-39.8 \mathrm{~mm} \mathrm{SL})$. PCA was performed on the co-variance matrix of the $20 \log$-transformed measurements. The locomotor activity rhythmicity was studied in laboratory under free running conditions (Trajano et al., 2009).

\section{Results}

\section{Aspidoras albater Nijssen \& Isbrucker, 1976}

Aspidoras albater Nijssen \& Isbrucker, 1976: 115, fig. 6. (Type locality: Brazil, Goiás, rio Tocantizinho, near São João da Aliança, $14^{\circ} 46^{\prime} \mathrm{S} 47^{\circ} 30^{\prime} \mathrm{W}$, rio Tocantins system).

Description. Comparative morphometric and meristic data shown in Table 1. General body shape in Figs. 1 - 2. Head robust, with dorsal profile nearly straight from snout tip to eye and slightly convex from that point to supraoccipital tip. Head and snout roughly triangular in dorsal aspect. Dorsal profile of body straight to slightly convex from tip of supraoccipital process to dorsal fin. Profile nearly straight to slightly concave from dorsal-fin spine to adipose fin; slightly concave from that point to caudal-fin base. Ventral profile straight to slightly convex from isthmus to anal-fin origin; slightly concave from that point to caudal-fin base.

Orbit highly variable among specimens, from nearly normal sized to completely obliterated by frontal, sphenotic, and infraorbital bones. Eyeball usually reduced in size, not visible externally, sometimes visible through bones when orbit obliterated. Mouth subterminal, approximately equal to internarial distance. Two pairs of maxillary and one pair of mental barbels.

Nasal, frontal, sphenotic, compound pterotic, and supraoccipital bones visible externally, devoid of odontodes. Fontanel ovoid and small, covered by thin skin and delimited only by frontal, not reaching supraoccipital. Supraoccipital fossa very small and covered by thin skin. Supraoccipital roughly quadrangular, with short posterior process separated from dorsal-fin nuchal plate by three dorsolateral body plates. Two infraorbital bones covered by thin skin and visible externally. Opercle visible externally, without odontodes. Preopercle covered by thin skin and visible externally; interopercle not visible externally, covered by thick skin.

Trunk lateral line reduced to two latero-sensory ossicles. Two series of elongate plates covering entire body. Nuchal plate covered by skin and not visible externally. Three to eight azygous plates anterior to adipose-fin spine. All plates with several minute odontodes restricted to posterior border. Cleithrum and coracoid covered by skin ventrally; cleithrum visible laterally. Dorsolateral body plates 26-27; ventrolateral body plates $23-24$. Abdomen entirely covered by scattered odontodes from isthmus to preanal area in adults; odontodes restricted to middle of abdomen in smaller specimens.

Dorsal fin nearly triangular, its origin just posterior to third dorsolateral plate. Ossified portion of dorsal-fin spine shorter than all branched rays; its posterior border smooth. Adipose fin triangular; its origin separated from base of last dorsal-fin ray by 9-10 dorsolateral body plates. Anal fin triangular, origin just posterior to $13^{\text {th }}-15^{\text {th }}$ ventrolateral body plate. Pectoral fin ovoid in shape, origin just posterior to gill opening. Ossified portion of pectoral-fin spine shorter than all branched pectoral- 
fin rays. Inner border of pectoral-fin spine slightly serrated. Pelvic fin ellipsoid, origin just posterior to third ventrolateral body plate, at vertical through base of third or fourth dorsal-fin ray. Caudal fin bilobed, both lobes with approximately same size. Upper and lower procurrent caudal-fin rays iv-v. All fins with minute odontodes scattered on all spines and rays.

Color in life. Whitish grey to slightly pink, with light grey pigmentation scattered on dorsal surface. Body with five inconspicuous broad saddles of grey pigmentation; first on predorsal plates, second below dorsal fin, third between dorsal and adipose fins, fourth below adipose fin, and fifth on posterior caudal peduncle. Dorsal, adipose and caudal fins with one or two bands of grey spots. Pectoral, pelvic, and anal fins unpigmented. Opercle reddish, due to underlying gill filaments seen by transparency. Some specimens very lightly colored, with faint spots, almost imperceptible. When exposed to continuous illumination in laboratory, fish became slightly darker (Fig. 1).

Color in alcohol. Generally whitish tan, same pattern as described above but grey pigmentation much fainter (Fig. 2).

Habitat, distribution and behavior. During our visit in the dry season of 2007, catfish were found throughout the small stream inside the cave Russão III and in the isolated pools of the cave Russão II. Fish were also observed in riffles with moderate water current, but they concentrated in slow moving, soft-bottomed pools with vegetal debris. Other fish were observed in the cave: trichomycterids, Ituglanis (6-7 specimens observed), and some characids.

Most of the time the catfish remained stationary on the sandy or rocky bottom, occasionally moving over short distances. When foraging on vegetal debris, rocks and crevices, they moved slowly, alone or in pairs, inspecting the substrate with the barbels and mouth. Occasionally, one individual followed the other, touching its rear with the mouth or barbels. No agonistic interactions were noticed. Only when disturbed by the observers they quickly moved away.

In laboratory, the catfish were kept collectively in an 801 aquarium, in the absence of light (except during maintenance activities and short, random periods of observation) and fed live Artemia crustaceans ad libitum, once or, less frequently, twice a week. These fish are quite tolerant to each other, sharing hiding places (limestone blocks); we did not observe agonistic interactions or other dominance behaviors. They behaved more actively than in the cave habitat, moving not only on the bottom but frequently also in midwater, occasionally surfacing to gulp air, apparently for neutral buoyance maintenance, as observed by Gee \& Graham (1987) for many callichthyids. Epigean Aspidoras catfish from São Domingos karst area, also observed in laboratory, were active

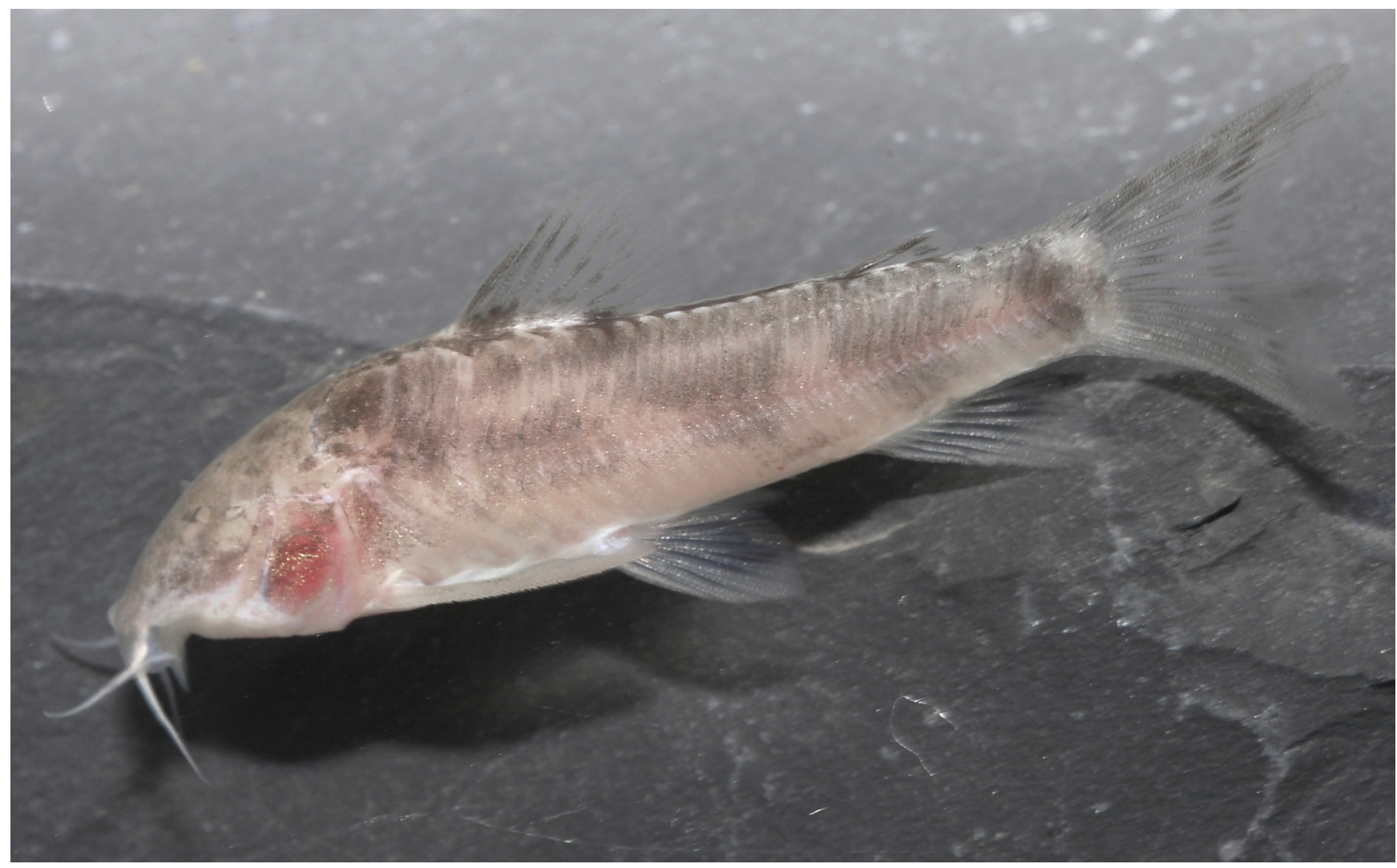

Fig. 1. Aspidoras albater, MZUSP 95905, about $25.0 \mathrm{~mm}$ SL, from Anésio III cave, Goiás, Brazil. Specimen kept in aquarium. Photo Alexandre Lopes Camargo. 


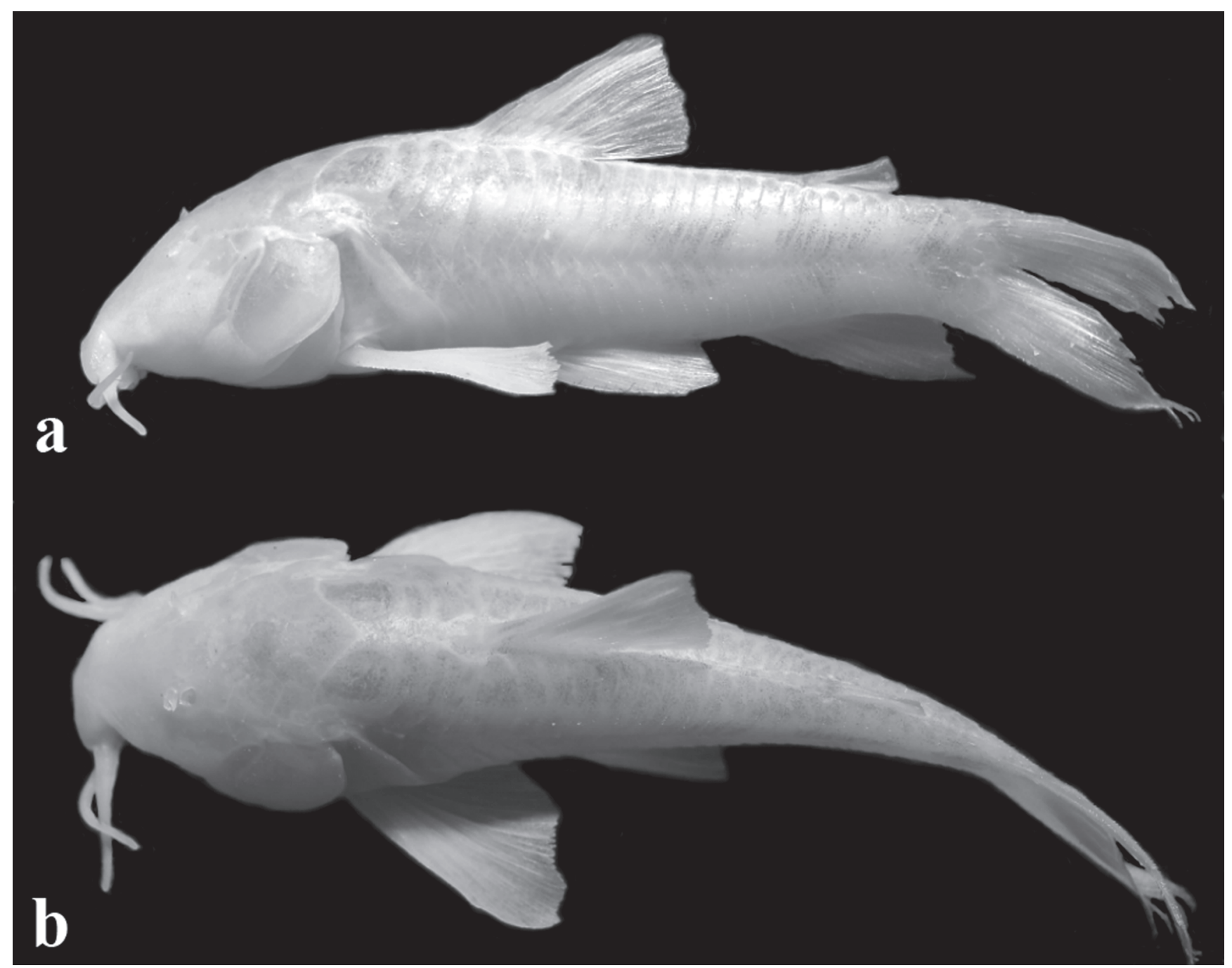

Fig. 2. Aspidoras albater, MZUSP 95905, $35.1 \mathrm{~mm} \mathrm{SL}$, from Anésio III cave, Goiás, Brazil. a) Lateral view; b) dorsal view. Photo Alexandre Camargo.

predominantly near the bottom, using the midwater less frequently than the cave specimens. The latter are very agile, jumping over barriers above the water surface and trying to climb water currents in the aquarium. All individuals promptly accepted live Artemia offered in laboratory, intensifying the midwater activity on such occasions.

Juveniles of the hypogean population born in laboratory at the beginning of 2009 were noticed when already $15+\mathrm{mm}$ long, all presenting visible eyes, as observed for all troglobitic vertebrates whose development was studied. One year later (March 2010), these specimens exhibited individual variability regarding eye development, from those with eyes as developed as in epigean fish (Fig. 5a) to individuals without externally visible eyes (Fig. 5d); intermediate stages were also present $($ Fig. $5 b, c)$. The individual growth rates are low - after three years in laboratory, the wild caught adults did not grow noticeably.

No circadian component was observed for one out of four studied specimens monitored under constant darkness, indicating an incipient regression in time keeping mechanisms parallel to that observed for eyes and pigmentation (Trajano et al., 2009).

Morphometrics. In a PCA with all measurements the first principal component included $64.9 \%$ of the total variance and all variable loadings were positive and varied little in magnitude, except for horizontal orbital diameter, which was strongly negative (loading $=-0.861$ ). Plots of factor scores of PC I vs. PC II grouped both cave populations in a broadly overlapping cluster and partially separated the epigean specimens (Fig. 3). Since the separation is on PC I and the orbital diameter was strongly negative, we believe that it represents a general size factor (Bookstein, 1989). Plots of factor scores of PC II $v s$. PC III grouped specimens into three broadly overlapping clusters (Fig. 3). PC II and III included 31.4 and $0.9 \%$ of the total variance, respectively. Measurement with heavier loading on PC II was again the horizontal eye diameter (-0.501), while loadings of all other measurements were around -0.2 ; heavier loadings on PC III are dorsal spine length (-0.916) and dorsal to adipose distance (0.189). 

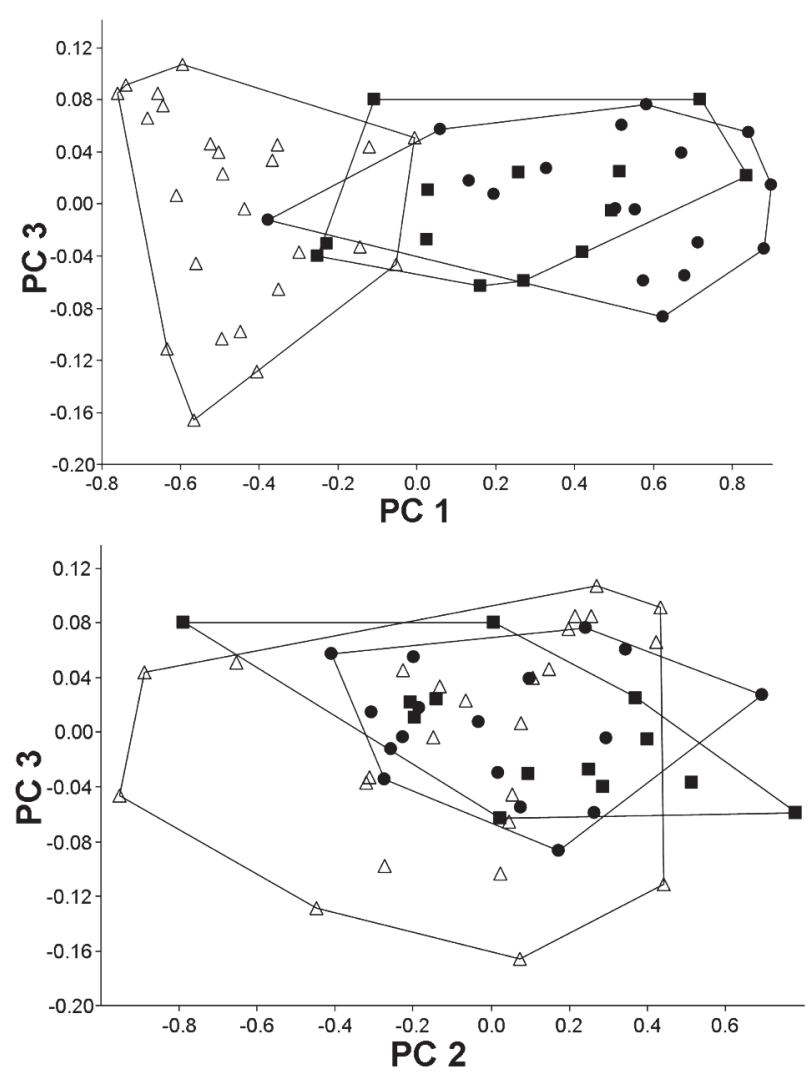

Fig. 3. Plots of factor scores of principal component analysis of three populations of Aspidoras albater, with all measurement included. Circle, Anésio III Cave; Square, Russão II Cave; triangle, epigean specimens.

On a second PCA we removed the three measurements that are directly influenced by the reduction of eyes (horizontal eye diameter, interorbital width, and snout length). In this case, the PC I included a large proportion of the total variance (90.6\%) and all variable loadings were positive and varied little in magnitude, suggesting that it represents a general size factor (Bookstein, 1989). Plots of factor scores of PC I vs. PC II grouped both cave population and the epigean specimens in a broadly overlapping cluster (Fig. 3). Plots of factor scores of PC II $v s$. PC III grouped specimens into three broadly overlapping clusters (Fig. 4). PC II and III included 2.4 and $1.7 \%$ of the total variance, respectively. The measurement with heavier loading on PC II was dorsal spine length (0.947), while loadings of all other measurements were negative and below -0.2 ; heavier loadings on PC III were adipose spine length $(-0.560)$ and dorsal to adipose distance (0.464).

The principal components analysis of morphometric traits failed to discriminate clusters among the two cave populations and among cave and epigean specimens, indicating that morphology not related to eye reduction is highly homogeneous. However, some morphological differences were found between specimens of the epigean populations when compared to specimens from the caves (Table 1). These
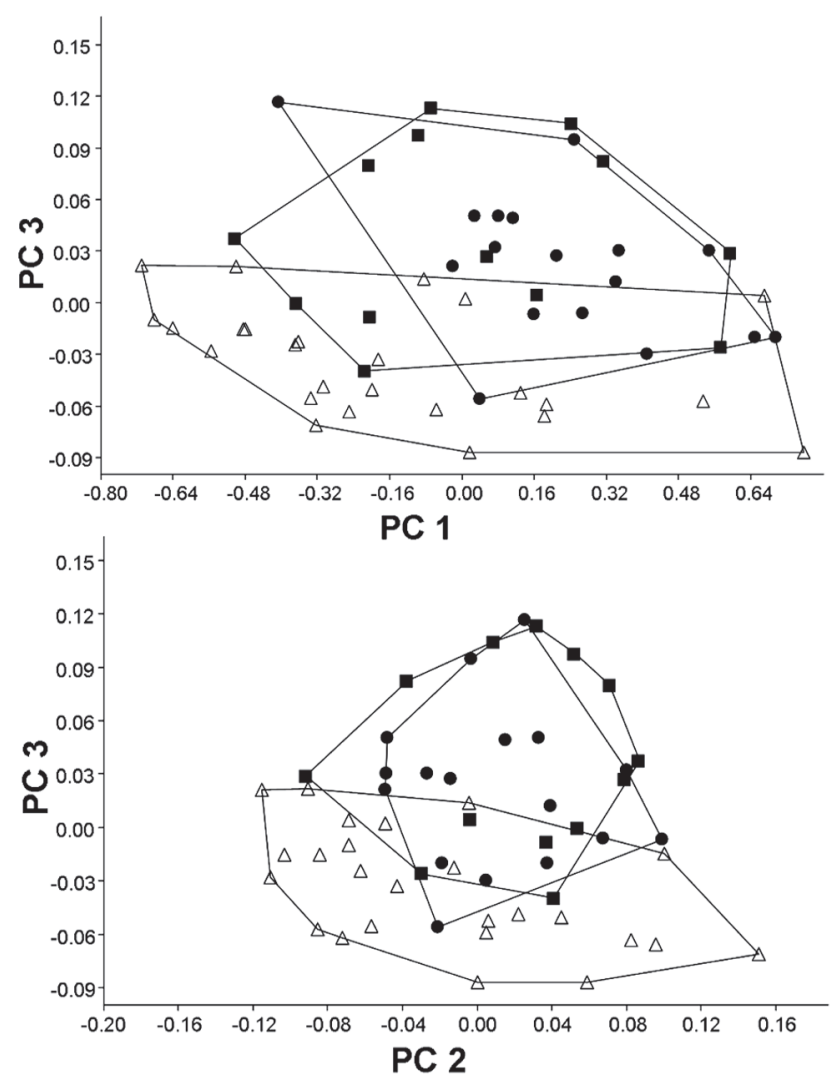

Fig. 4. Plots of factor scores of principal component analysis of three populations of Aspidoras albater, excluding measurements related to eye reduction (horizontal orbital diameter, least interorbital distance, and snout length). Circle, Anésio III Cave; Square, Russão II Cave; triangle, epigean specimens.

differences are mainly related to proportions of the head, as head depth, least interorbital distance, horizontal orbital diameter, snout length, and least internareal distance. All these features, however, are probably influenced by modifications of the head morphology caused by the reduction of the eye and orbit, making it difficult to interpret. The taxonomic situation of Aspidoras albater and other potentially undescribed species of Aspidoras in the upper rio Tocantins is in need of attention, and the differences found between the epigean and the cave populations may not be sufficient to delimit a separate species. These differences must be investigated based on a much larger sample and broader geographic representation and using both morphological and molecular evidence.

\section{Discussion}

The São Domingos karst area is distinguished worldwide by its rich subterranean ichthyofauna, including eight previously reported troglobitic species (Mattox et al., 2008): five trichomycterids, genus Ituglanis, one heptapterid, Pimelodella 


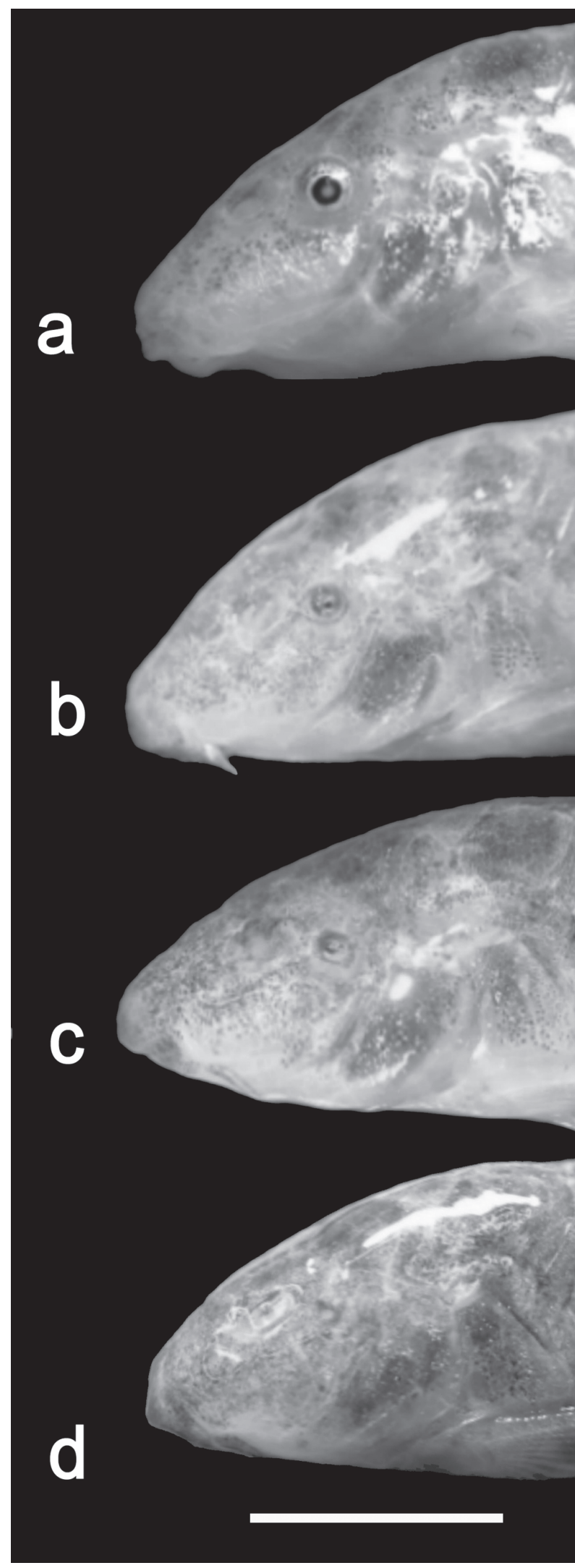

Fig. 5. Eye variation in 15 months old juveniles of cave Aspidoras albater born in laboratory. a) eye apparently functional; b) and c) eye severely reduced and possibly non functional; and d) eye covered and non functional. Scale bar $=5 \mathrm{~mm}$. spelaea Trajano, Reis \& Bichuette, 2004, one loricariid, Ancistrus cryptophthalmus Reis, 1987, with four cave populations showing a mosaic distribution of troglomorphic character states (Reis et al., 2006), and one gymnotiform, Eigenmannia vicentespelaea Triques, 1996 (see Bichuette \& Trajano, 2006, for an expanded diagnosis). The presently studied Aspidoras armored catfish, which live in the neighborhood of the Parque Estadual de Terra Ronca, represents the eighth troglomorphic fish for São Domingos karst area, and the first known callichthyid showing troglomorphic traits.

It is expected to find populations displaying an incipient degree of differentiation, as witnesses of an ongoing process caught up at an early stage and which may or may not proceed in the same direction. The recognition of the status of separate, nominal species is always difficult for populations in this grey area, as would be the case of the presently studied cave callichthyids, and the cutoff point is always a matter of debate among specialists. In any case, we have no doubt that these cave Aspidoras populations are undergoing a process of genetic differentiation, which includes the reduction of eyes and pigmentation, in conditions of (at least partial) isolation in the subterranean habitat. A comprehensive taxonomic revision of Aspidoras, however, would be instrumental, as this cave population might eventually be recognized as a separate taxon depending on the diagnoses of its congeners.

Not surprisingly, a low degree of troglomorphism is also observed in other cave fishes from São Domingos karst area, as is the case with Eigenmannia vicentespelaea, Pimelodella spelaea, and Ituglanis mambai Bichuette \& Trajano, 2008. These species have been diagnosed based on a combination of character states, including eyes that are reduced when compared to epigean congeners found in the same river basins. It is noteworthy that the variation in eye reduction and the proportion of individuals with highly reduced to externally not visible eyes is higher in these cave Aspidoras than in the three species mentioned above.

Troglobitic vertebrates born in laboratory (fishes and salamanders) so far studied are born with developed eyes, which regress during the ontogeny (Secutti \& Trajano, 2009). This process has long been known and described for troglobitic Mexican tetra characins, genus Astyanax (Peters \& Peters, 1973; Wilkens, 2010). Therefore, the present observations are consistent with the observed patterns for underground vertebrates. The individual variability in eye development exhibited by juveniles born in laboratory is seemingly genetic because these catfish were kept under the same conditions (in the same aquarium, fed ad libitum, and without noticeable dominance). Specializations to the subterranean life also include behavioral traits such as regression of circadian rhythmicity and intensification of midwater activity, as frequently observed in troglobitic fishes (Parzefall \& Trajano, 2010).

The cave populations of Aspidoras albater are biometrically distinct from the epigean populations analyzed herein. Table 1 shows at least nine morphometric and meristic traits (marked with an asterisk) that distinguish cave from epigean populations, and five of those are not related to the eye reduction. Among 
these later ones, the head depth (63.6-75.8\% SL in the cave population vs. 82.4-110.2\% SL in the epigean population) and the maxillary barbel length $(36.4-58.95 v$ v. $51.4-85.1 \% \mathrm{HL}$ ) are the most remarkable. In the later case, we would expect that cavedwelling specimens had longer maxillary barbels, since they act as a tactile organ during foraging.

In the absence of conclusive diagnostic characters and following the taxonomic criteria practiced for the genus, we choose to assign the cave Aspidoras from Posse to the nominal species $A$. albater, emphasizing the evolutionary tendencies which are exclusive to the subterranean populations and parallel those observed for other troglobitic fishes. The ontogenetic evidence for the eye variability in adults point to a differentiation in progress, probably due to isolation in subterranean streams. The Aspidoras from Posse would be referred to as $A$. albater cave form, as has been the practice for some other cave fishes, such as the Mexican Poecilia mexicana from Cueva de las Sardinas (= Cueva de Villa Luz or Cueva del Azufre) and Astyanax mexicanus from Sierra El Abra, and the catfish Rhamdia guatemalensis (e.g., Fack \& Wilkens, 1989; Behrens et al., 1998, Junge, 1992; Proudlove, 2010).

Cave specimens examined. Brazil: Goiás: rio Tocantins basin: MZUSP 95905, 19, 21.0-38.8 mm SL, caverna Anésio III, 1405'27.7'S 46 22' 59.6”'W, Posse. MZUSP 95906, 13, 18.9-36.2 mm SL, caverna do Russão II, $14^{\circ} 05^{\prime} 05.3^{\prime}$ ’S 46²3'07.1”W, Posse.

Comparative material examined: Brazil, Goiás State, rio Tocantins basin: Aspidoras albater MZUSP 49853, 5, 17.8-37.9 $\mathrm{mm}$ SL, riacho at Serra da Mesa, 13 ${ }^{\circ} 52^{\prime} 06^{\prime}$ 'S 48²3'20"W, Campinaçu. MZUSP 40650, 20, 16.8-39.8 mm SL, creek tributary to córrego Mandassaia, itself a tributary to rio Manso, $22 \mathrm{~km}$ from Campos Belos on road GO-447, $13^{\circ} 10^{\prime} \mathrm{S} 46^{\circ} 42^{\prime} \mathrm{W}$, Monte Alegre.

\section{Acknowledgements}

We are deeply indebted to José A. O. Motta, chief manager of the CECAV-IBAMA/GO, who first reported the occurrence of the cave Aspidoras and lead us to their caves, together with members of the CECAV staff, José E. T. Alarcão, Marco A. L. Olive, and Geovana M. V. Rosa. Thanks are also due to the biologists who helped us with the fieldwork, especially to Maria E. Bichuette, Ana L. F. Guil, and Vanessa Felice, and the speleologist Ericson C. Igual (Speleology Group Pierre Matin - GPME). RER and ET are partially financed by CNPq (respectively processes \# 303362/2007-3 and 308634/2007-1).

\section{Literature Cited}

Behrens, M., H. Wilkens \& H. Schmale. 1998. Cloning of the alpha A-crystallin genes of a blind cave form and the epigean form of Astyanax mexicanus: a comparative analysis of structure, expression and evolutionary conservation. Gene, 216: 319-326.

Bichuette, M. E. \& E. Trajano. 2003. Epigean and subterranean ichthyofauna from São Domingos karst area, upper Tocantins River basin, Central Brazil. Journal of Fish Biology, 63: 1100-1121.

Bichuette, M. E. \& E. Trajano. 2006. Morphology and distribution of the cave knifefish Eigenmannia vicentespelaea Triques, 1996
(Gymnotiformes: Sternopygidae) from Central Brazil, with an expanded diagnosis and comments on subterranean evolution. Neotropical Ichthyology, 4: 99-105.

Bookstein, F. L. 1989. "Size and Shape": A comment on semantics. Systematic Zoology, 38: 173-180.

Fack, H. \& H. Wilkens. 1989. Eye reduction in hybrids and a naturally viable cave form of Astyanax mexicanus (Characidae, Pisces). Mémoires de Biospeologie, 16: 157-161.

Junge, P. 1992. Egg size and larval development of epigean and cave forms of Rhamdia guatemalensis (Pimelodidae, Pisces). GSFBericht, 7: 165-173.

Mattox, G. M. T., M. E. Bichuette, S. Secutti \& E. Trajano. 2008. Surface and subterranean ichthyofauna in the Serra do Ramalho karst area, northeastern Brazil, with updated lists of Brazilian troglobitic and troglophilic fishes. Biota Neotropica, 8: 145-152.

Parzefall, J. \& E. Trajano. 2010. Behavioral patterns in Subterranean Fishes. Pp. 81-114. In: Trajano, E., M. E. Bichuette \& B. G. Kapoor (Eds.). Biology of Subterranean Fishes. Science Publ., Enfield, 480p.

Peters, N. \& G. Peters. 1973. Problèmes génétiques de l'évolution régressive dês cavernicoles. Annales de Spéléologie, 28: 301-313.

Proudlove, G. 2010. Biodiversity and Distribution of the Subterranean Fishes of the World. Pp. 41-63. In: Trajano, E., M. E. Bichuette \& B. G. Kapoor (Eds.). Biology of Subterranean Fishes. Science Publ., Enfield, 480p.

Reis, R. E. 1997. Revision of the neotropical catfish genus Hoplosternum (Ostariophysi: Siluriformes: Callichthyidae), with the description of two new genera and three new species. Ichthyological Exploration of Freshwaters, 7: 299-326.

Reis, R. E. 2003. Family Callichthyidae. Pp. 291-309. In: Reis, R. E., S. O. Kulander \& C. J. Ferraris, Jr. (Eds.). Check List of the Freshwater Fishes of South and Central America, Edipucrs, Porto Alegre, 729p.

Reis, R. E., E. Trajano \& E. Hingst-Zaher. 2006. Shape variation in surface and cave populations of the armoured catfish Ancistrus (Siluriformes; Loricariidae) from the São Domingos karst area, upper Tocantins River, Brazil. Journal of Fish Biology, 68: 414-429.

Secutti, S. \& E. Trajano. 2009. Reproductive behavior, development and eye regression in the cave armored catfish, Ancistrus cryptophthalmus Reis, 1987 (Siluriformes: Loricariidae), bred in laboratory. Neotropical Ichthyology, 7: 479-490

Trajano, E. 1991. Population ecology of Pimelodella kronei, troglobitic catfish from Southeastern Brazil (Siluriformes, Pimelodidae). Environmental Biology of Fishes, 30: 407-421.

Trajano, E., 2001. Ecology of subterranean fishes: an overview. Environmental Biology of Fishes, 62: 133-160.

Trajano, E. 2007. The challenge of estimating the age of subterranean lineages: examples from Brazil. Acta Carsologica, 36: 191-198.

Trajano, E. \& M. E. Bichuette. 2010. Subterranean Fishes of Brazil. Pp. 331-355. In: Trajano, E., M. E. Bichuette \& B. G. Kapoor (Eds.). Biology of Subterranean Fishes. Science Publ., Enfield, 480p.

Trajano, E., M. R. Carvalho, L. Duarte \& L. Menna-Barreto. 2009. Comparative study on free-running locomotor circadian rhythms in Brazilian subterranean fishes with different degrees of specialization to the hypogean life (Teleostei: Siluriformes, Characiformes). Biological Rhythm Research, 40: 477-489.

Wilkens, H. 2010. Genes, modules and the evolution of cave fish. Heredity 2010: 1-10.

Submitted October 7, 2010

Accepted July 20, 2011

Published December 26, 2011 